\title{
TRIM24 wt Allele
}

National Cancer Institute

\section{Source}

National Cancer Institute. TRIM24 wt Allele. NCI Thesaurus. Code C95282.

Human TRIM24 wild-type allele is located within 7q32-q34 and is approximately $130 \mathrm{~kb}$ in length. This allele, which encodes transcription intermediary factor 1-alpha protein, is involved in transcriptional regulation. Genetic mutation and a translocation $t(7 ; 10)$ (q32;q11) involving this gene and the human RET gene are associated with thyroid papillary carcinoma. 